Ярошенко Ірина Володимирівна, кандидат мистецтвознавства, доцент, доцент кафедри методики музичного виховання та диригування

Навчально-наукового інституту мистецтв Прикарпатського національного університету імені Василя Стефаника

ORCID ID 0000-0002-0097-5276

yaroshenko_roman@ukr.net

\title{
СПЕЦИФІКА КОМПОЗИТОРСЬКОЇ ТВОРЧОСТІ АНДРІЯ КУШНІРЕНКА
}

Метою статті - охарактеризувати та розглянути специфіку композиторської творчості Андрія Кушніренка, визначити його роль у культурно-історичних процесах розвитку музичного мистецтва Буковини другої половини ХХ століття. Методологія дослідження полягає в застосуванні матеріалів, які характеризують динаміку розвитку композиторської діяльності Андрія Кушніренка та тенденцій, що сприяли розвитку музичної культури й творчого доробку митця. Наукова новизна роботи полягає в тому, що вперше досліджено характерні особливості композиторської діяльності митця Буковини А. Кушніренка другої половини XX століття в різних його складових: композиторська творчість, громадська, диригентсько-хорове виконавство, тобто тих здобутків, що сприяли відродженню та розвитку професійно-виконавських i культурнопросвітницьких традицій Буковини. Висновки. В результаті дослідження розкрито особливості та специфіку творчої діяльності А. Кушніренка у контексті становлення професійного диригентсько-хорового мистецтва, зроблено характеристику композиторської творчості відомого митця. Проаналізована роль буковинського фольклору у його мистецькій спадщині та особливості його використання в авторських хорових обробках та інших за жанрами оригінальних творах, визначений внесок А. Кушніренка як композитора, фольклориста у справу збереження і пропаганди буковинської обрядової культури з використанням сучасних технологій.

Ключові слова: мистецтво, Буковина, музична культура, диригентсько-хорова діяльність, композиторська творчість.

Ярошенко Ирина Владимировна, кандидат искусствоведения, доцент кафедры методики музыкального воспитания и дирижирования Учебно-научного института искусств Прикарпатского наиионального университета имени Василия Стефаника

Специфика композиторского творчества Андрея Кушниренко

Целью статьи - охарактеризовать и рассмотреть специфику композиторского творчества Андрея Кушниренко, определить его роль в культурно-исторических процессах развития музыкального искусства Буковины второй половины XX века. Методология исследования заключается в применении материалов, характеризующих динамику развития композиторской деятельности Андрея Кушниренко и тенденций, способствовали развитию музыкальной культуры и творчества художника. Научная новизна работы заключается в том, что впервые исследованы характерные особенности композиторской деятельности художника Буковины А. Кушниренко второй половины XX века в разных его составляющих: композиторское творчество, общественная, дирижерско-хоровое исполнительство, то есть тех достижений, которые способствовали возрождению и развитию профессионально-исполнительских и культурно-просветительских традиций Буковины. Выводы. В результате исследования раскрыты особенности и специфику творческой деятельности А. Кушниренко в контексте становления профессионального дирижерско-хорового искусства, сделано характеристику композиторского творчества известного художника. Проанализирована роль буковинского фольклора в его художественном наследии и особенности его использования в авторских хоровых обработках и других по жанрам оригинальных произведениях, определенный вклад А. Кушниренко как композитора, фольклориста в дело сохранения и пропаганды буковинской обрядовой культуры с использованием современных технологий.

Ключевые слова: искусство, Буковина, музыкальная культура, дирижерско-хоровое деятельность, композиторское творчество.

Yaroshenko Iryna, Ph.D. of Arts, Associate Professor of the Methodology of Musical Education and Conducting of the Educational and Scientific Institute of Arts of the Precarpathian National University named after Vasyl Stefanyk

The specificity of compositor's article Andry Kushnirenko

The purpose of the article is to characterize and consider the specifics of Andrei Kushnirenko's composer's work, to determine his role in the cultural and historical processes of the development of musical art of Bukovina in the second half of the twentieth century. The methodology of the research is to apply materials that characterize the

(C) Ярошенко I. В., 2019 
dynamics of the development of Andriy Kushnirenko's composer activity and the tendencies that contributed to the development of musical culture and creative work of the artist. The scientific novelty of the work is that for the first time the characteristic features of the composer's activity of the artist of Bukovina A. Kushnirenko of the second half of the twentieth century in various components have been explored for the first time: composer creativity, public, conductor-choral performance, that is, those achievements that have contributed to the revival and development of professional-performing and cultural and educational traditions of Bukovina. Conclusions. As a result of the research, the features and specifics of A. Kushnirenko's creative activity in the context of the formation of professional conductive-choral art are revealed, and the composer's work of the famous artist is described. The role of the Bukovinian folklore in his artistic heritage and the peculiarities of its use in author's choral works and other genres of original works are analyzed, A. Kushnirenko's contribution as a composer, folklorist in the preservation and propagation of the Bukovinian ritual culture with the use of modern technologies is determined.

Key words: art, Bukovina, musical culture, conductor-choral activity, composer's creativity.

Актуальність теми дослідження Посилює необхідність більш предметного вивчення буковинської культури наявність яскравих постатей, якими вона представлена, особливо у другій половині XX столітті. Серед них - фундатор і керівник Буковинського ансамблю пісні і танцю, диригент, фольклорист, педагог, композитор, з іменем якого пов’язана музична історія буковинського краю Андрій Кушніренко.

Аналіз досліджень і публікацій. Багатогранність його музичної діяльності неодноразово привертала увагу відомих діячів української науки і мистецтва: А. Гнатишина, М. Головащенка, А.Добрянського, А. Мокренка, О. Правдюка, М. Ткача та інших, які у своїх висловлюваннях і відгуках - оцінках його творчості підкреслюють вагомість внеску, що зробив А. Кушніренко у розвиток професійно-хорового виконавства на Буковині, й історичну значущість його діяльності у збереження та розвиток музично-просвітницьких традицій цього краю. Але на сьогодні немає досліджень, які б системно і цілісно відтворювали протікання культурологічного процесу у цьому ареалі, і в тому числі, його складової - музичної творчості. Посилює необхідність більш предметного вивчення композиторської творчості Андрія Кушніренка. Отже, актуальність дослідження зумовлена недостатнім вивченням композиторської діяльності А. Кушніренка, необхідністю використання творчого доробку митця та важливістю об’єктивної оцінки його ролі в розвитку національної культури.

Мета статті - охарактеризувати композиторську творчість Андрія Кушніренка, напрямки та специфіку професійної музичної культури, які відбувалися на Буковині у другій половині ХХ століття.

Виклад основного матеріалу. Вивчаючи композиторську творчість А. Кушніренка, розкриваємо його власний мистецький почерк, стильово-визначальні елементи музичної мови, яскравість і колоритність художньої образності творів та особливості власного музичного стилю.

У доробку композитора: одноактна народна опера «Буковинська весна» на лібрето А.Добрянського (1968), музика до героїко-романтичної драми «Полум'я» С. Снігура (1977), кантата «Молюсь за тебе, Україно» на власні слова для мішаного хору, соліста баритона і симфонічного оркестру(1993), поема «Славен Хотин-град» на слова В. Микитюк (2002), присвячена 1000-літтю м. Хотина; вокально-хореографічні композиції: «Щедрий вечір, добрий вечір», «Весна-красна», «Весільний обряд», «Обжинки», «Зелен край наш Буковина» та ряд інструментальних творів: «Балада для 2-х скрипок і фортепіано» (1998), «Експромт» для фортепіано (1993). Наявність вищеназваних творів свідчить про те, що композитор тяжіє до великих форм. Але один із характерних видів творчості А. Кушніренка - обробка народних пісень та твори для хору і солістів, зокрема «Любіть Україну» на вірші В. Сосюри (2000), «Україно, любов моя» (1984) та «У вінок Федьковичу» (1987) на вірші М. Ткача, «Ранок Верховини» на слова В. Колодія, «У космосі Україна» на вірші Т. Севернюк, «Зореслава» і «Я щаслива зроду» на вірші І. Кутеня, «Запалали очі зорями» на вірші М. Бакая, «Мир народам» і «Дума про Сагайдачного» на власні слова (1991); понад 1000 записаних народних пісень та інструментальних мелодій, більше сотні з яких оброблено для хору і оркестру, зокрема «Ой, у лузі червона калина», «Чом, чом, земле моя», «Садок вишневий коло хати», «Подоляночка», «На камені стою», «Глибока кирниця», «Палала сосна», а також танці: «Аркан», «Метелиця», «Червона калина» та інші. Цікава різножанрова творчість А. Кушніренка стала вагомим надбанням для скарбниці української музики.

Протягом всього свого творчого життя А. Кушніренко плідно працював у жанрі хорової музики. У доробку композитора різні типи хорових партитур за жанрами і тематикою, хори для однорідних жіночих та чоловічих складів, мішані хори a'cappella та з інструментальним супроводом. 
«Хори А. Кушніренка - це цікаві витончені темброві та гармонічні, художньо-образні картини. Стиль, в основному гомофонно-поліфонічний, засобами якого розкривається основний зміст твору» $[5,9]$.

А. М. Кушніренко багато писав творів для хору «Резонанс» кафедри музики Чернівецького національного університету ім. Ю. Федьковича, до якого мав особливий підхід як керівник та справжній майстер своєї справи. Нелегка наполеглива праця А. Кушніренка - диригента, композитора, організатора відкривав чудовий світ молодих талантів і була справжньою мистецькою лабораторією для студентів. Уміння працювати над строєм, інтонацією хору, застосовуючи своєрідні форми і методи, виливається в те, що в кінцевому підсумку звучання того чи іншого твору насичене мереживом чистих кольорів справжнього мистецтва.

«Улюблений студентами, викладачами, професорами «Гімн Чернівецького національного університету ім. Ю. Федьковича» на слова Богдана Мельничука, музику до якого А. Кушніренко написав 3 великої щани і любові до рідного університету та своїх вихованців, став студентським гімном, який звучить у стінах університету і $€$ його гордістю» $[4,133]$. Серед хорових творів А.Кушніренка слід назвати поему «Славен Хотин-град» на слова В. Микитюк, яка вперше виконувалася 21 вересня 2002 року на урочистому концерті, присвяченому 1000-літтю м. Хотина, зведеним хором і солістом у супроводі симфонічного оркестру. Ці твори можна віднести до пісеньгімнів, на яких композитор виховує у студентів почуття патріотизму і любові до рідної землі, до свого народу. Він передає власні знання, вміння, мистецький дух своїм вихованцям, які є свідками творчого процесу - народження нових музичних перлин. «Професор глибоко відтворює ідейний зміст творів та наповнює їх натхненням, глибиною образів і професійною музичною мовою» $[4,136]$. Разом 3 тим, А. Кушніренко звертався до кращих музичних зразків, виховуючи у молоді повагу до творчої спадщини українських композиторів. Спілкування з видатними митцями України, які безпосередньо вплинули на творчу особистість Андрія Миколайовича, створило прекрасну мистецьку ауру. Ще 3 молодих літ неабиякі здібності А. Кушніренка помітили такі диригенти львівської школи, як С.Прокоп'як, І. Небожинський, М. Антків, О. Сотничук, В. Василевич, Є. Вахняк; творчі зустрічі та спілкування з С. Людкевичем, М. Колессою, А. Кос-Анатольським, А. Солтисом, Я. Вощаком, С.Турчаком, П. Муравським та іншими видатними майстрами хорової справи залишили незабутній слід на мистецькій стежині А. Кушніренка, який продовжив їх справу, примножуючи мистецьке надбання української національної культури.

Серед різножанрової творчості А. Кушніренка можна виділити його відому кантату «Молюсь за тебе, Україно», створену для соліста баритона, мішаного хору і симфонічного оркестру. Це одночастинна композиція, викладена у контрастно-складовій формі. Творові властивий наскрізний розвиток. У побудові кантати можна виділити три розділи. Вони втілюють, так би мовити, різні ступені молитовного стану - від благального звернення до Господа з проханням уберегти Україну від лиха, через молитовно-просвітлене прохання «Господи помилуй» до урочистого, піднесеного апофеозу «Многая літа».

Перший розділ викладений у тональності ре-мінор. У своїй будові він має ознаки безрепризної тричастинності. Музиці цього розділу властивий драматизм, напруженість і динамізм гармонічного розвитку. Тут ніби втілено страждання народу, його біль за долю України, за іï майбутне.

Другий розділ має авторську ремарку Religioso. Це молитовне благання Господньої милості. «Сонячний» ре-мажор втілює стан умиротворення і гармонії. У завершенні цього розділу линуть прохання простити провини. Це природна і невід'ємна частина молитовного звернення до Бога. Тут змінюється тональність. Звучить мі-мінор, який згодом переходить у соль-мажор, готуючи появу третього, заключного розділу твору. Урочисто, яскраво, святково і піднесено звучить «Многая літа». Барвисте. Соковите tutti хору і оркестру природно завершує всю композицію.

Андрій Кушніренко у своїй творчості велику увагу приділяє Шевченковому слову. Заслуговують уваги його обробки, що відзначаються оригінальністю звучання. Серед них: «Заповіт», «Реве та стогне Дніпр широкий», «Садок вишневий коло хати», «Плавай, плавай, лебедонько».

У музичній мові А. Кушніренка вдало поєднувалися найкращі зразки фольклору та професійне мистецтво. Пошуки нових виражальних засобів, театральні співставлення і колористичні ефекти, застосування принципи монотематизму характеризують стильові ознаки творів композитора. Великого значення він надає засобам поліфонічного розвитку, збагаченню гармонії, частим змінам, які відбуваються в результаті варіаційного проведення теми, вживанню збільшених та зменшених акордів, модуляційним змінам. Діапазон гармонічних засобів: від найпростіших класичних послідовностей до складних побудов із застосуванням цікавих сучасних гармоній. Композитор 
користувався прийомами співставлення голосів і груп, вдало застосовує динамічні зміни. Працюючи над хоровими обробками, А. Кушніренко опирається на ладо-гармонічну сторону музичної мови, найбільше це помітно в «Коломийках», «Щедрівках», буковинських народних піснях. «Митця приваблював основний настрій мелодії, ії глибина, тому народні пісні в обробці А. Кушніренка - це «живі» музичні образи, різножанрові сцени 3 народного життя» $[2,136]$. Він прагнув передати загальний емоційний тонус пісні цікавою гармонією, використанням септакордів головних і побічних ступенів, застосуванням імітації та іншою технічною майстерністю.

Висновки. Характеризуючи специфіку творчої діяльності А. Кушніренка у контексті становлення професійного диригенсько-хорового мистецтва, необхідно підсумувати, що композитор об'єднував своє творче бачення з образом пісні, розкриваючи найтонші почуття, та відтворював у ній життя народного духу. Його композиторська діяльність $\epsilon$ великим внеском у відродження і розвиток української музичної культури. Подальше вивчення специфіки творчої діяльності А. Кушніренка дає перспективну можливість значно глибше дослідити загальний розвиток професійної музичної культури Буковини.

\section{תimepamypa}

1. Демочко К. Музична Буковина. Київ: Музична Україна, 1990. С. 18, 44.

2. Кушніренко А. Розвиток української музичної культури на Буковині другої половини XIX - поч. XX ст. П’ятий конгрес міжнародної асоціації україністів. Соціально-гуманітарні науки. Чернівці: Рута, 2004. С. 213.

3. Павлюк О. Буковина. Визначні постаті 1774 - 1918 (біографічний довідник). Чернівці: Золоті литаври, 2000. $136 \mathrm{c}$.

4. Ярошенко I. В. Мистецтвом встелені шляхи. Андрій Кушніренко - диригент, композитор, педагог. Чернівці: Прут, 2004. 220 с.

5. Ярошенко I. В. Принципи формування образного мислення диригента в творчому процесі А. Кушніренка. Актуальні проблеми історії, теорії та практики художньої культури. Зб. наук. праць. Вип. XIV. Київ: Міленіум, 2005. С. 177-183.

6. Ярошенко I. В. Музичне краєзнавство Західної України XIX - XX століть: професійно-хорове мистецтво Буковини. Київ: Білий Тигр, 2015. 220 с.

\section{References}

1. Democko, K. (1990). Musical Bukovina. Kyiv: Musical Ukraine. P. 18, 44 [in Ukrainian].

2. Kushnirenko, A. (2004). Development of the Ukrainian musical culture in Bukovina of the second half of the XIX - beginning. Twentieth century Fifth Congress of the International Association of Ukrainianists. Social and Humanitarian Sciences. Chernivtsi: Ruta [in Ukrainian].

3. Pavlyuk, O. (2000). Bukovina. Famous figures from 1774-1918 (biographical guide). Chernivtsi: Gold Lithavers [in Ukrainian].

4. Yaroshenko, I.V. (2004). The art of the paths are laid. Andriy Kushnirenko - conductor, composer, teacher. Chernivtsi: Prut [in Ukrainian].

5. Yaroshenko, I.V. (2005). Principles of formation of imaginative thinking of conductor in the creative process A. Kushnirenko. Actual problems of history, theory and practice of artistic culture. $\mathrm{Zb}$ sciences works Whip XIV. Kyiv: Millennium. P. 177-183 [in Ukrainian].

6. Yaroshenko, I.V. (2015). Music local studies of Western Ukraine of the XIX-XX centuries: vocational and choral art of Bukovina. Kyiv: White Tiger [in Ukrainian].

Стаття надійшла до редакиії 04.12.2018 p. 